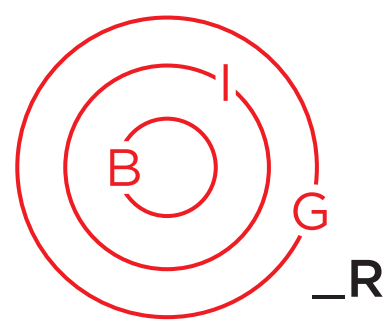

REVIEW ESSAY

\title{
New Border Studies On Israel/Palestine: Review of Two Books
}

\author{
Daniel Meier *
}

The Politics of Maps: Cartographic Constructions of Israel/Palestine.

By Christine Leuenberger \& Izhak Schnell

Oxford University Press, 2020.

Hardback, 252 pages, 47 maps and figures ISBN: 9780190076238

Ebook available

https://global.oup.com/academic/product/the-politics-of-maps-9780190076238?cc=fr\&lang=en\&

Penser la Palestine en réseaux

Edited by Véronique Bontemps, Nicolas Dot-Pouillard, Jalal al-Husseini \& Abaher al-Sakka

Diacritiques Editions \& Presses de l'ifpo, 2020

Paperback, 257 pages.

ISBN: 9791097093105

https://diacritiques.hypotheses.org/1568
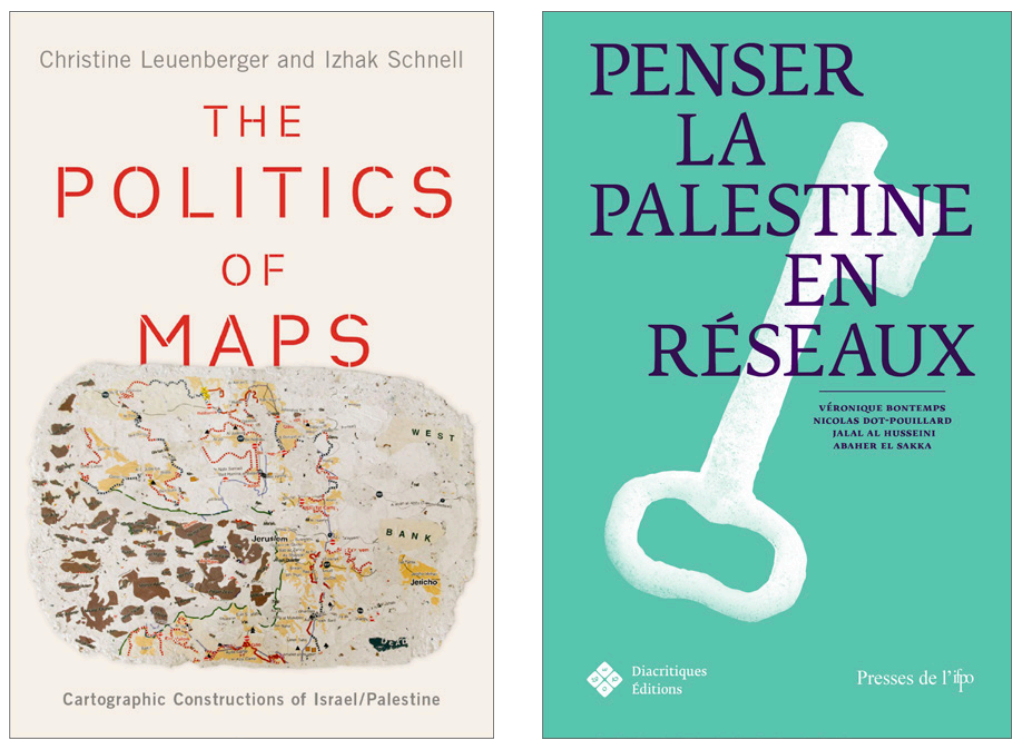

Border studies have investigated the Israeli-Palestinian space as fruitful for conceptualization given the matrix of control the Israeli state has dispatched over the whole territory over the last decades. The two recent books selected here are part of an attempt to conceptualize Israel and Palestine beyond the classical tools of border studies while investigating firstly the Israeli construction of cartographic material to represent the ongoing conflict and secondly the concept of network to think about Palestine beyond its borders. Both are worth reading for different reasons but share a common attempt to rejuvenate our perspective on this inextricable conflict.

The fascinating book written by Christine Leuenberger and Izhak Schnell is the result of longstanding research that took years to appear in the final format of this book. And the result is worth waiting for. Published by Oxford University Press, The Politics of Maps will stay as a reference in the field of cartographic research applied to a rather complex case study, Israel-Palestine. This elegant and compact text provides the reader with dense material crafted with theoretical tools, narratives, documents and maps (some in color). Aside from the book's pleasant aesthetics, it shows determination to dig through layers of ideologies and to get to the root of this complex conflict that is shattering the land of IsraelPalestine. Nine chapters and a short conclusion wrapped up in a 200-page well written book with an attractive front cover-a map of present-day Jerusalem and its surroundings-cannot leave the reader indifferent. The sub-title Cartographic Constructions of Israel/Palestine gives the angle on which the book relies, and the first

* Daniel Meier, PhD, Political Scientist and Lecturer at the Global Studies Institute, University of Geneva, and
associate researcher at the CNRS PACTE Grenoble, France. Contact: daniel.meier@graduateinstitute.ch

BIG_Review journal homepage: https://journals.uvic.ca/index.php/bigreview

Borders in Globalization homepage: https://biglobalization.org/ 
pages outline more precisely the intent to investigate "how maps serve as rhetorical tools to advocate for particular, socially constructed, value laden, and ideologically charged geopolitical visions" (p.2).

Why maps? This original angle allows the authors to go beyond the classical conception of map as either purely scientific or willfully propagandistic. All maps are necessarily selective, contingent and contextual, as Kitchin and Dodge ("Rethinking Maps" in Progress in Human Geography 31(3), 2007) would recall, reflecting on the production of reality, as maps helped to create nations, boundaries, spatial imaginations and national identities, and also because they are continuously made and re-made. This critical cartography delves into each map to ground an interpretative analysis on visual signifiers (scale, symbols, level of detail, choice of contrast, colors and visual metaphors), textual signifiers (naming, headings, written justification and methods showing the audience targeted), the demarcation of the space (creating spatial orders and hierarchies by including or excluding borders, routes, and sites). Maps are therefore understood as discourses but not only. The authors also highlight the role and function of maps in the nation-state building by tracing the history of mapping and the social, cultural and political context of their production, with maps stemming from different horizons and political or private groups. The research is obtained through various qualitative methodologies, including interviews with map-makers and state officials, NGO workers, academics, international organization workers, and other stakeholders, providing the authors with insights "from above" and "from below" in the field of map-making.

In the second and third chapters, the authors examine first the role of cartography in the shaping of the territorial entity of the state of Israel alongside the role of many other actors, among them the geographers. They underscore the key aspect of science and technology as resources to shape the state and the belief in a biopolitics capable of knowing, managing and improving Israeli society within its territory. It is of key importance to consider that the British Mandate of Palestine shared with the Zionists a modernist ethos. While the British registered the land and established a survey of the population, the Hagannah (ancestor of the Israeli Defence Forces) looted the Survey of Palestine and accessed the cartographic material which helped them to win the war in 1948 and facilitated statecraft. The Israeli state then introduced a new land tenure system that clashed with the traditional Ottoman land allocation practices and lead to a massive dispossession of many Arab landowners and landholders: 93 percent of the land thus became Israeli state land! Far from ratifying this process, the authors highlight the fact that such scientific and legal paradigms of Western influence is not in itself responsible for this outcome but that Israeli surveyors who were registering the land had a collectivist Zionist and nationalist vision and contributed by their methods to the "Israelization of the lands" (pp.47-55).
The fourth chapter deals with the key role played by the Jewish National Fund in the aftermath of Israeli independence as a socializing agent into notions of territory with the dissemination of the "blue boxes" used to collect donations and buy land in the "Holy Land". The authors remind that "re-naming territory is a pre-condition for the transfer of territorial control" (p.11). That is also the duty of the Names Committee that established a Hebrew toponomy of the land. An atlas soon helped to shape the representation of Israel's national story, Zionist achievements and technical prowess. The next two chapters focus on the period after the 1967 war, when Israel more than tripled the territories under its control. While chapter five highlights the spreading of the maps throughout the society and more particularly from right-wing movements, embodying three different expansionist visions of the land of Israel, be it secular, religious or linked to the settlers, chapter six shows how the left-wing and human rights organizations also deployed maps to tell their geopolitical vision including proposal for territorial compromises, even retracing alternative Arab topography of hundreds of erased villages in the search for historical justice, like the NGO Zochrot, relying on the work of Palestinian historians and some critical Israeli historians.

Chapter seven deals with the significance of international borders with neighboring states and the Green Line with the Palestinians. Despite all the technical skills, the boundary-making of Israel shows the limits of the capacity of any government to try to reunite a territorial expansionist ideology with a technocratic solution delineating borders. This very important chapter probably lacks some visual illustrations and maps which may have shown the applied Zionist ideology on the neighboring states' sovereign territories (the Syrian Golan Heights, the West Bank which had been under Jordanian control, the Egyptian Sinai Peninsula, and the south of Lebanon). Chapter 8 comes back to the dire Palestinian situation and restrictions of access to resources after the Oslo Accord (1993) due to Israel's monopoly over the tools to implement it. Chapter 9 concludes with the idea that surveying, mapping and planning are crucial to establishing the legitimacy and functionality of a future state like Palestine. Moreover, their attempts to map their land contradict Israeli mapping and reveal silences and omissions that will continue to haunt the Israeli-Palestinian conflict.

Resulting from a transnational seminar held for four years in the Lebanese, Jordanian and Jerusalemite branches of the French Institute of the Near East, the second book Penser la Palestine en Réseaux (Thinking Palestine in Networks) offers a cross-border reflection on the Palestinian area, starting from the concept of network. The ambition here is to get away from an overhanging vision as much as to escape a state-centered perspective. To do this, the editors, the anthropologist Véronique Bontemps who has been leading a seminar on Palestine in Paris for ten years, as well as Nicolas Dot-Pouillard, Jalal 
al-Husseini and Abaher al-Sakka, all three well-known political scientists, explain in introduction the ambivalent relation of the notion of network, straddling social science analysis tools and practices of social mobilization. This last aspect brings to light a double critique, that of democratic centralism and that of partisan structures as the exclusive mode of practicing politics. Consequently, the work consists in "thinking the networks which think themselves in networks" (p.14) (present translations by D. Meier) thus showing the exchanges which occur between the theoretical and the political. Faced with this practical and disciplinary polysemy, the introduction sets out a minimum definition: networks are seen as "the expression of social relations which go beyond codified political, institutional and economic relations" (p.15). A liminal concept, the network is therefore considered here as both a model of action and a category of analysis. Equipped with this double-focal lens, the contributions then unfold a fine series of field surveys giving pride of place to ordinary practices in the family, economic, virtual or religious fields of Palestinian society. In doing so, the network concept intends to link what borders separate and isolate: The Occupied Palestinian Territories, the State of Israel, the refugee camps in neighboring countries and of course the Palestinian diaspora which spans all continents.

The book, elegantly presented by the young publishing house Diacritiques Editions, is divided into two parts, each of four investigative articles written mainly by young researchers. In the first section dedicated to militant networks, Elsa Grugeon opens the volume with a catchy title: "Al-Aqsa 2.O. Abolishing borders and challenging the constraint on the Internet" which starts from the observation that the Dome of the Rock and the al-Aqsa mosque, the third holiest site in Islam, are today cut off from a significant part of the Palestinian community and from the Muslim community. And the author asks the question: "in what way do the internet and new media form a resource for overcoming borders and territorial constraints as well as for mobilizing?" (p.27). She then shows how young Palestinians living in East Jerusalem promote a commitment, understood as an intermediation mission but also as a militant act, around the Al-Aqsa mosque as an icon of Palestinian territoriality in Jerusalem and as an observation of the logics of closures / openings to its access. In addition to the notorious importance taken by social networks in recent years, she recalls that the role of the internet is to establish links between those who live near this holy place and those who are distant from it, beyond local and international borders. Amusingly, she notes that the Arabic lexical field of the word "link" refers to the Islamic term ribât which designated the ascetic and warlike posture of the defenders of Islamic territory on its fringes in the early days of Islam. These border guards or murabitûn are today embodied by young Palestinians, guardian of the links of the Al-Aqsa site with the rest of the world.
The mobilization potential of networks is also measured with non-Palestinians labeled "international" living in Palestine by Clio Chaveneau's survey. Internationally, Nicolas Dot-Pouillard investigates the case of the networks mobilized for Palestinian rights in France. He thus shows how this "French passion" that is Palestine has been largely dominated over the long term by "the left of the left" in a "horizontal, flexible, informal, grafted or connected" mode of mobilization" (p.119) and whose transnational dimension deserves to be linked on a global scale which would make it possible to testify to a political, aesthetic and international appropriation of the Palestinian cause by multiple leftist groups far beyond the borders of Palestine.

Other chapters detail the social aspects of networks such as that of Minas Ouchaklian on the networks of Fatah militants as resources in power struggles, or of Mariangela Gasparotto on the networks of new arrivals in Ramallah who bring to light the spatialization of the hierarchies and statutory inequalities. The more transnational angle devoted to the second part is well embodied by the articles of Jalal al-Husseini, Marion Slitine and Najla NakhléCerruti, respectively centered on the Palestinian diaspora, on the networks of contemporary art and theatrical practice in Gaza. All three illustrate the ways of reinventing a national imagination that is deployed beyond territorial borders by using the means available in the global sphere. If the decline in the capacity to mobilize for the right of return or against the recent American decisions to transfer the US embassy to Jerusalem seems obvious, this disenchantment, Jalal al-Husseini tells us, does not signal the disappearance of the Palestinian diaspora but rather its withdrawal into "networks woven across borders by refugee families” (p.205). For her part, Marion Slitine shows that the strong localism which continues to mark the practices of contemporary Palestinian art must be understood as a form of resistance and an affirmation of identity at the crossroads of a growing globalization of this artistic sector and increased fragmentation of the Palestinian territories. With Larissa Sansour's emblematic installation showing a cosmonaut planting the Palestinian flag on the moon, one could conclude, with Appadurai, that the circulation of images, works, or men across spaces is continually eroding the multiple borders of nation-states. And raises the question of the birth of a new post-national space.

In sum, both books provided some complementary tools to think about the Israel-Palestine space as a territory, a representation and a place of living. While the first book highlighted the various dimensions of the social construction of cartography and their implications, the second one shows the importance of networks as resourceful tools to apprehend the social realities and imaginaries of nowadays Palestine, beyond its strictly territorial grounding. 